\title{
Effects of Oleracein E and Oleracein L from Portulaca oleracea on Cell Survival, Antioxidant and Antidiabetic Efficacy on $\beta$-TC-6 Pancreatic Cell Line
}

\author{
HANIE ROOZI, M. N. AKBAR BOJAR ${ }^{1 *}$, V. EIDI AND K. N. R. ALI² \\ Department of Biology, Science and Research Branch, Islamic Azad University, Tehran, 1Department of Biochemistry, Faculty \\ of Science, Kharazmi University, Tehran, ${ }^{2}$ Faculty of Sciences, Kharazmi University, Tehran, Iran
}

\section{Roozi et al.: Effects of Oleracein E and Oleracein L from Portulaca oleracea}

\begin{abstract}
Oleracein $\mathrm{E}$ and oleracein $\mathrm{L}$ are the major bioactive isoquinoline alkaloids in Portulaca oleracea. Here, the effects of these alkaloids on cell survival, the activity of superoxide dismutase, catalase, and glutathione peroxidase, factors associated with oxidative stress such as malondialdehyde and dityrosine, carbohydratehydrolyzing enzymes $\alpha$-amylase and $\alpha$-glucosidase, insulin secretion levels and glucose uptake ability were investigated. The $\beta$-TC- 6 pancreatic cell line was incubated with oleracein $E$ and $L$ at concentrations of 0,50 , 100,200 and $400 \mu \mathrm{M}$ and tested separately. All biological assays were based on UV/Vis spectrophotometric and/or high performance liquid chromatography methods. Oleracein $E$ and $L$ at $100 \mu M$ concentrations increased antioxidant activity of enzymes. In addition, the total oxidative damage biomarkers ablated significantly in 50 and $100 \mu \mathrm{M}$ concentrations, which could be due to the positive effect of antioxidant enzymes on biomarker level. Similar inhibition properties were shown by $\alpha$-amylase and $\alpha$-glucosidase and consequently, the investigated alkaloids could exhibit the high hypoglycemic effect. Furthermore, glucose uptake and insulin secretion were enhanced by these compounds. Hence, these alkaloids have considerable antioxidant and potential hypoglycemic effects on the pancreatic cell line and they could be suggested for future studies in the treatment of diabetes mellitus.
\end{abstract}

Key words: Antioxidant enzyme, antidiabetic indicators, oxidative stress levels, oleracein $\mathrm{E}$, oleracein $\mathrm{L}$, $\beta$-TC6 cell line

Diabetes mellitus (DM) is a widespread and growing metabolic disorder distinguished by the lack of the body's ability to regulate glucose and insulin homeostasis ${ }^{[1]}$. Considering the increased risk of diabetic microvascular (retinopathy, nephropathy, and neuropathy) and macrovascular complications (heart attacks and strokes), now DM has become a serious public health problem ${ }^{[2]}$. Hence, studying DM-related mechanisms and development of new antidiabetic drugs is important. The secretion of insulin from beta cells of the pancreas plays a key role in all types of DM especially type one ${ }^{[3]}$. Among the common risk factors affecting the secretion of insulin, oxidative stress is regarded to be a determining aspect in the onset and promotion of DM. The mechanism by which oxidative stress disrupts insulin secretion is often complex and involves several cell signaling pathways ${ }^{[4]}$.

Malondialdehyde (MDA) is a side product of lipid peroxidation, it may be a stage of cellular damage and

*Address for correspondence E-mail: mboojar@yahoo.com

July-August 2019 is known as an oxidative stress marker in cells and tissues ${ }^{[5]}$. Several vessel diseases are caused by lipid peroxidation ${ }^{[6,7]}$. Protein oxidation forms dityrosine (DTY), which is created by various oxidative systems. In this respect, it has been introduced as a main biomarker for oxidatively modified proteins in response to stress caused by various factors ranging from UV and gamma-irradiation, aging, and exposure to oxygen free radicals ${ }^{[8]}$. Superoxide dismutase (SOD), catalase and glutathione peroxidase (GPx) play a key role in protection against free radicals ${ }^{[5]}$.

One of the treatment strategies in non-insulin-dependent DM is to delay the absorption of glucose by inhibition

This is an open access article distributed under the terms of the Creative Commons Attribution-NonCommercial-ShareAlike 3.0 License, which allows others to remix, tweak, and build upon the work non-commercially, as long as the author is credited and the new creations are licensed under the identical terms

Accepted 11 June 2019

Revised 16 March 2019

Received 13 November 2018

Indian J Pharm Sci 2019;81(4):681-689 
of sugar hydrolyzing enzymes, such as $\alpha$-glucosidase and $\alpha$-amylase, in the gastrointestinal tract ${ }^{[9]}$. Natural products as the inhibitors of carbohydrate-hydrolyzing enzymes and their hypoglycemic potential have been considered as a new treatment for $\mathrm{DM}^{[10]}$.

In the treatment of DM, medicinal plants are used in traditional medicines and in many cases they have fewer side effects compared to synthetic drugs ${ }^{[10,11]}$. Furthermore, many existing drugs are derived from the herbs $^{[11]}$. Purslane (Portulaca oleracea) plant is one of the most extensively used healthful plants listed within the World Health Organization ${ }^{[12]}$. The plant contains carbohydrates, sterols, lipids, alkaloids (including oleraceins), coumarins and flavonoids ${ }^{[13-15]}$

Alkaloids can reportedly act differently in various concentrations. Some of the foremost vital effects of alkaloids include their antidiabetic, antioxidant and medicament activities ${ }^{[16,17]}$. Purslane is a tropical herb and traditional Chinese medicine used as food for patients suffering from vessel diseases and furthermore, some pharmacological effects, including neuroprotective, antiproliferation, antiinflammatory, antihyperlipidemic, and antidiabetic properties have been described ${ }^{[18-21]}$.

Oleracein E (OL-E) and oleracein L (OL-L) are the major bioactive isoquinoline derivatives in purslane and the examination of the antioxidant properties, oxidative stress level and antidiabetic indicators of these alkaloids at different concentrations on pancreatic beta cells are necessary ${ }^{[22,23]}$. In this study, the effects of mentioned alkaloids of Portulaca oleracea were investigated using several assays in $\beta$-TC-6 pancreatic cell lines. Therefore, evaluation of cell survival, antioxidant enzyme activity (SOD, catalase, and GPx), lipid peroxidation (MDA and DTY assays), glucose uptake, insulin secretion levels, and $\alpha$-amylase and $\alpha$-glucosidase inhibitory activity of investigated isoquinolines at concentrations of $0,50,100,200$ and $400 \mu \mathrm{M}$ were examined.

\section{MATERIAL AND METHODS}

\section{Preparation $\beta$-TC-6 pancreatic cell line:}

Mouse $\beta$-TC-6 pancreatic cell line was obtained from the Pasteur Research Institute (Tehran, Iran). $\beta$-Cells were grown in Dulbecco's modified Eagle medium (DMEM) and $10 \%$ heat-inactivated fetal bovine serum (FBS), followed by the addition of $1 \%$ penicillin and streptomycin antibiotics. The cultures were kept in a humid incubator at $37^{\circ}$ in $5 \%$ carbon dioxide and the growth medium was replaced with fresh medium every three days ${ }^{[24]}$. The other used reagents and OL-E and OL-L were bought from Sigma Chemical Co., St. Louis, MO, USA.

To prepare the lysates of mouse $\beta$-TC- 6 cells attached to the culture plate were scraped off with a cell scraper and collected in a $1.5 \mathrm{ml}$ tube by centrifugation. The cell pellets were rinsed with PBS, suspended in sterile water, and then lysed by sonication. The cells were seeded at $1 \times 106$ cells $/ \mathrm{ml}$ and subcultured every two days after $60-80 \%$ confluence was reached. For each experiment, the cells were treated separately with increasing concentrations of oleracein derivatives $(0,50,100,200$ and $400 \mu \mathrm{M})$ and incubated for $24 \mathrm{~h}$. The control wells received medium without isoquinoline derivatives. Also, each experiment was replicated three times.

\section{Superoxide dismutase (SOD) activity assay:}

The $\beta$-TC-6 cell culture medium was incubated with different concentrations of OL-E and OL-L independently for $24 \mathrm{~h}$. Kono method was then used to measure the enzyme activity in the $\beta$-TC- 6 cell line extract. In this technique, hydroxylamine, aqueous tetrazolium nitroblue (NBT) and $2 \mathrm{M}$ sodium carbonate were poured into a tube, followed by the addition of the buffer, extract and $1.0 \mathrm{mM}$ ethylenediaminetetraacetic acid (EDTA). The NBT absorption was measured at $560 \mathrm{~nm}$ compared to the aqueous NBT $4 \mathrm{mg} / \mathrm{ml}^{[25]}$.

\section{Catalase activity assay:}

The enzyme activity was measured at $240 \mathrm{~nm}$ on the basis of the hydrogen peroxide decomposition. The cell line $(0.1 \mathrm{mg} / \mathrm{ml}$ of protein) was added to one $\mathrm{ml}$ of the reaction mixture containing $15 \mathrm{mM}$ hydrogen peroxide, $50 \mathrm{mM}$ monopotassium phosphate and $0.1 \%$ Triton X-100 at pH 7.4. One unit of enzyme activity is defined as one mmol of hydrogen peroxide consumed per min per $\mathrm{mg}$ of protein ${ }^{[26]}$. The concentration of proteins was measured using the bicinchoninic acid protein assay kit (Sigma-Aldrich, St. Louis, MO), in which bovine serum albumin was used as a standard.

\section{Glutathione peroxidase (GPx) activity assay:}

In this method, cell line extract $(0.1 \mathrm{mg} / \mathrm{ml}$ of $\mathrm{GPx}$ enzyme) was suspended at $30^{\circ}$ in the reaction mixture containing $1 \mathrm{mmol}$ of glutathione, 0.96 units $/ \mathrm{ml}$ of GPx enzyme, $100 \mathrm{mmol}$ of EDTA, $50 \mathrm{mmol}$ of potassium phosphate ( $\mathrm{pH}$ 7.4). $150 \mathrm{mmol}$ of nicotinamide adenine dinucleotide phosphate (NADPH) and $1.2 \mathrm{mM}$ of tert- 
butyl hydroperoxide were then added to this suspension. To start the reaction, $50 \mu \mathrm{l}$ of $\mathrm{H}_{2} \mathrm{O}_{2}$ substrate was added to the reaction mixture. Absorbance was measured at $340 \mathrm{~nm}$. The extinction coefficient of $6.22 \mathrm{mM}^{-1} \mathrm{~cm}^{-1}$ was used to determine the units of enzyme activity. One unit of GPx used $1 \mathrm{nmol}$ NADPH consumed/min/ $\mathrm{mg}$ of $\operatorname{protein}^{[27]}$.

\section{Malondialdehyde (MDA) level measurement:}

A solution of trichloroacetic acid (TCA) and the extract of $\beta$-TC- 6 cells lysate were mixed in a tube. The tube was then placed in an incubator for $15 \mathrm{~min}$ on a warm water bath, followed by the addition of thiobarbituric acid (TBA). In the Wills method, MDA and TBA were combined at $90-100^{\circ}$ under acidic conditions and TBA reactive pink material formed. The absorbance against blank was then read at $532 \mathrm{~nm}^{[28]}$.

\section{DTY level measurement:}

DTY was detected by reversed-phase high-performance liquid chromatography and UV detector in $280 \mathrm{~nm}$ and combined with radiation fluorescence light. The extracts and TCA were combined in a tube. The gradient was $10 \mathrm{mM}$ ammonium acetate, adjusted to $\mathrm{pH} 4.5$ with acetic acid and methanol, starting with $1 \%$ methanol and increasing to $10 \%$ over a period of thirty minutes. The supernatant $(100 \mu \mathrm{l})$ was loaded on to a Superdex 75 10/300 GL size exclusion column (GE Healthcare Life Science) at a flow rate of $0.8 \mathrm{ml} / \mathrm{min}$. The DTY level was expressed as $\mu \mathrm{M} / \mathrm{g}$ of the $\operatorname{protein}^{[29]}$.

\section{$\alpha$-Amylase activity assay:}

About $500 \mu \mathrm{l}$ of the sample, $500 \mu \mathrm{l}$ of $0.02 \mathrm{M}$ sodium phosphate buffer ( $\mathrm{pH} 6.9$ with $0.006 \mathrm{M}$ sodium chloride) and $5 \mathrm{mg} / \mathrm{ml} \alpha$-amylase solutions were incubated at $25^{\circ}$ for $10 \mathrm{~min}$. $\alpha$-amylase from Grampositive bacteria was obtained from Sigma Aldrich Chemical Co. (USA). About $500 \mu \mathrm{l}$ of $1 \%$ starch solution in $0.02 \mathrm{M}$ sodium dihydrogen phosphate buffer (pH 6.9 with $0.006 \mathrm{M} \mathrm{NaCl}$ ) was added to tubes. The mixture obtained was then incubated for $10 \mathrm{~min}$ at $25^{\circ}$. The reaction was stopped by adding $1 \mathrm{ml}$ of dinitrosalicylic acid dye. Afterwards, the tubes were heated in boiling water for $5 \mathrm{~min}$ and then cooled to ambient temperature. In this method, acarbose was a positive control. The absorption was recorded at $450 \mathrm{~nm}$ using a multimode reader after the addition of $10 \mathrm{ml}$ of distilled water. The results were reported as the percent of inhibitory activity of the enzyme ${ }^{[30]}$.

\section{$\alpha$-Glucosidase activity assay:}

$\alpha$-Glucosidase from brewer's yeast was obtained from Sigma Aldrich Chemical Co. (USA). Then $20 \mu \mathrm{l}$ of $\alpha$-glucosidase were mixed with $200 \mu$ of the test compounds in $50 \mathrm{mmol}$ of phosphate buffer at $\mathrm{pH} 6.8$. The reaction mixture was incubated for $5 \mathrm{~min}$ at $37^{\circ}$. $200 \mathrm{ml}$ of para-nitrophenyl- $\alpha$-D glucuronide and $50 \mathrm{ml}$ of phosphate buffer were mixed and the reaction started. The mixture was incubated at $37^{\circ}$ for $20 \mathrm{~min}$. Acarbose was used as the positive control. The reaction ended upon the addition of $500 \mu \mathrm{l}$ of $1 \mathrm{M}$ sodium carbonate. The final volume was $1500 \mu \mathrm{l}$. The absorbance was recorded at $405 \mathrm{~nm}^{[31]}$.

\section{Glucose uptake assay:}

Beta-TC-6 pancreatic cells were settled at a density of $1.5 \times 10^{4}$ cells $/ \mathrm{ml}$ in a plate at $37^{\circ}$ in $5 \% \mathrm{CO}_{2}$. They were incubated overnight, the medium was discarded, washed with phosphate-buffered saline (PBS) twice and refilled with $2.5 \mathrm{mM}$ glucose in DMEM without glucose, supplemented with L-glutamine and $15 \%$ (v/v) PBS. The cells were incubated for $60 \mathrm{~min}$ at $37^{\circ}$ in $5 \% \mathrm{CO}_{2}$. The conditioning medium was replaced with $10 \mathrm{mM}$ 2-NBD glucose (Invitrogen) in basal medium. The cells were exposed at $37^{\circ}$ in $5 \% \mathrm{CO}_{2}$ for half an hour. The medium was then removed and the cells were washed two times with PBS. The cells were ultimately stained with Hoechst 33342 nucleic dye for $30 \mathrm{~min}$. Intracellular fluorescence light was observed in the cells at the excitation to emission ratio of 350/461 and 475/550 for Hoechst 33342 and 2-NBD glucose, respectively. ArrayScan High Content Screening (HCS) system (Cellomics Inc., Pittsburgh, PA, USA) was used to evaluate the plates, which were then analysed using Target Activation BioApplication software (Cellomics Inc.) ${ }^{[32]}$.

\section{Insulin secretion assay:}

Beta-TC-6 cells were cultured in a medium, which contained $100 \mathrm{U} / \mathrm{ml}$ penicillin, $11.1 \mathrm{mM}$ glucose with $10 \%$ FBS and $100 \mu \mathrm{g} / \mathrm{ml}$ streptomycin. The medium was changed every other day. Each cell was cultured for five days. $\beta$-TC- 6 pancreatic cells were settled into a plate at a density of $2 \times 10^{5}$ cells/well and grown for a day. The cells were washed two times, followed by incubation for $30 \mathrm{~min}$ in Krebs-Ringers bicarbonate buffer (115 mM sodium chloride, $4.7 \mathrm{mM}$ potassium chloride, $2.56 \mathrm{mM}$ calcium chloride, $1.2 \mathrm{mM}$ potassium dihydrogen phosphate, $1.2 \mathrm{mM}$ magnesium sulfate, $20 \mathrm{mM}$ sodium bicarbonate, $16 \mathrm{mM}$ 4-(2-hydroxyethyl)- 
1-piperazineethanesulfonic acid and $0.3 \%$ serum albumin at $\mathrm{pH}$ 7.4. Afterwards, the cells were incubated with Krebs-Ringer modified buffer, which contained $11.1 \mathrm{mM}$ glucose for $1 \mathrm{~h}$ at $37^{\circ}$. The contents of the cells were then centrifuged and the supernatants were equally divided and stored at $-20^{\circ}$. Mouse insulin enzyme-linked immune sorbent serologic assay kit was used to determine the level of insulin secretion ${ }^{[33]}$.

\section{Cell viability assay:}

According to the instruction provided by Young FM, determination of cell survival was performed using the 3-(4,5-dimethylthiazol-2-yl)-2,5diphenyl tetrazolium bromide (MTT) ${ }^{[34]}$. The assay was based on the generation of a blue formazan product by the dehydrogenase enzymes found in living cells. Briefly, after incubation of the $\beta$-TC-6 pancreatic cells with different dose levels of OL-E and OL-L, cells were washed and seeded in 96 well plates. Then MTT solution added to reach the final concentration of $0.5 \mathrm{mg} / \mathrm{ml}$ and after $3 \mathrm{~h}$ incubation, the culture medium was discarded and dimethyl sulfoxide was added. Finally, the optical density was detected by using spectrophotometer at 540 and $630 \mathrm{~nm}$. The separate experiments were repeated three times and the results presented as survival percentages compared to controls.
Statistical analysis:

The experiments were carried out in the concentration range of 0-400 $\mu \mathrm{M}$ OL-E and OL-L. Experiments were performed in triplicate and the average and standard deviation were calculated. The results obtained by ANOVA test were analysed by SPSS software (version 19.0) and were then statistically compared with the control group $(\mathrm{p}<0.05)$. IC50 and EC50 values for each alkaloid were determined by GraphPad Prism software (version 6.07).

\section{RESULTS AND DISCUSSION}

The results showed that $100 \mu \mathrm{M}$ of OL-E considerably increased the activities of SOD, catalase, and GPx to $22.10,15.62$ and $29.83 \%$, respectively. OL-L at a dose of $100 \mu \mathrm{M}$ remarkably increased the activities of SOD, catalase, and GPx to $15.78,19.56$ and $11.60 \%$, respectively, compared to the control $(\mathrm{p}<0.05$, figs. $1 \mathrm{~A}$, $\mathrm{B}, \mathrm{C})$. On the basis of the EC50 analysis, there was no statistical significance between studied derivatives (figs. 1D, E, F).

The results showed that $100 \mu \mathrm{M}$ OL-E considerably decreased the amount of MDA to $18.64 \%$. In addition, 50 and $100 \mu \mathrm{M}$ concentrations of OL-E decreased DTY levels to 15.93 and $8.83 \%$, respectively, relative to the
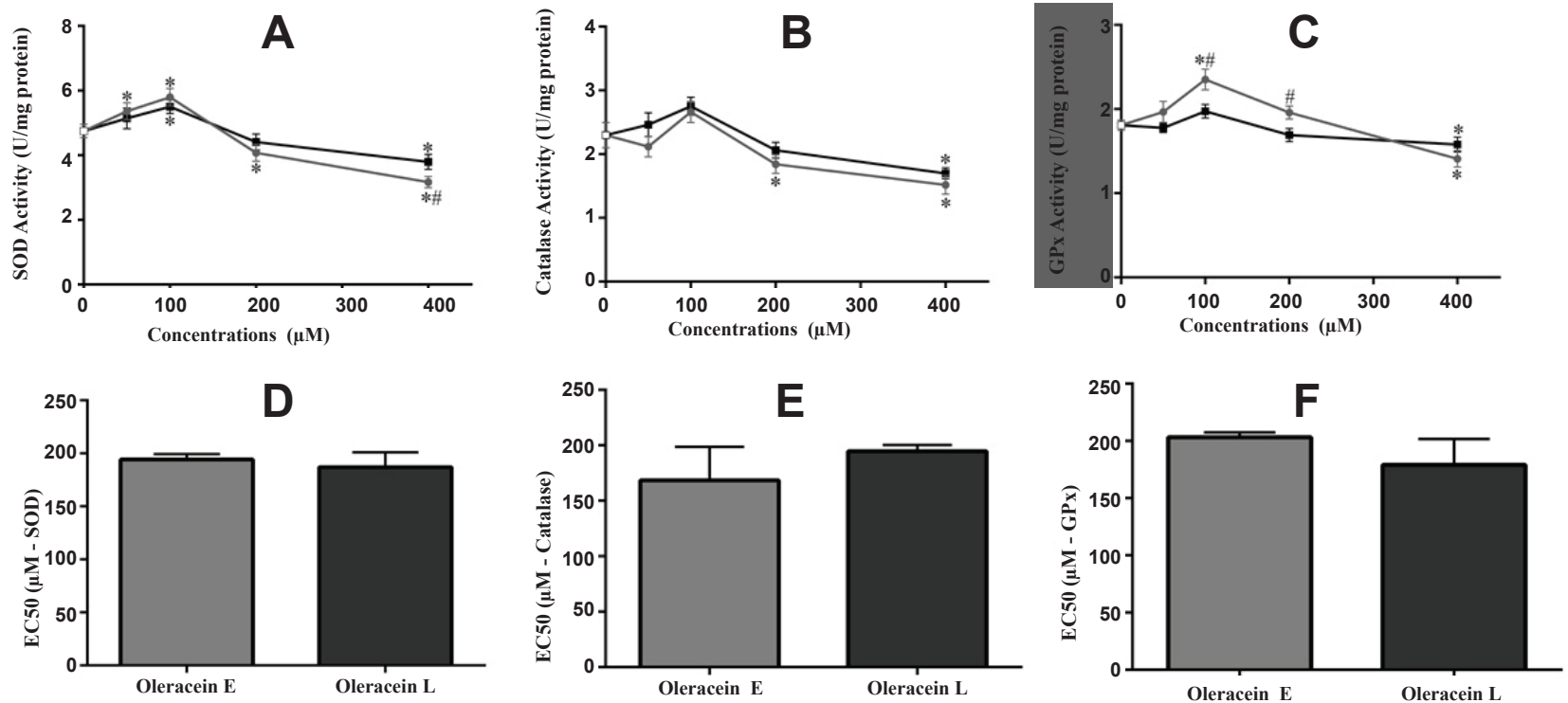

Fig. 1: Oleracein $E$ and oleracein $L$ effects on antioxidant enzyme activities

(A, B and C) Superoxide dismutase (SOD), catalase and glutathione peroxidase (GPx) activities of $\beta$-TC-6 pancreatic cells as U/mg of protein after $24 \mathrm{~h}$ treatment with different levels of OL-E and OL-L that determined by the optical absorbance measurements. Biological response of each compound evaluated independently in cell lysate samples. All data are presented as mean \pm SD; $n=3$. *Significant difference at $\mathbf{p}<\mathbf{0 . 0 5}$ in comparison to control according to one-way ANOVA, followed by Tukey's post hoc test. "Significant difference of OL-E compared to OL-L at the same concentration; (- $\square)$ control, (- --$)$ OL-E, (- E and F) EC50 values of studied compounds for SOD, catalase and GPx activities in investigated cells. All data are shown as mean \pm SD. There was no statistically significant difference between groups 
control. Using 50 and $100 \mu \mathrm{M}$ concentrations of OL-L reduced the amount of MDA to 8.94 and $18.64 \%$, respectively. DTY levels decreased to 4.51 and $9.57 \%$, respectively, relative to the control using the same OL-L concentrations ( $\mathrm{p}<0.05$, fig. 2 ).

The amount of $\alpha$-amylase remarkably decreased using 50 to $400 \mu \mathrm{M}$ concentrations of OL-E and OL-L compared to the control (fig. 3A). On the other hand, the $\alpha$-glucosidase activity was reduced by higher concentrations of these essential compounds relative to the control (fig. 3B). Additionally, data obtained from IC50 analysis revealed a significant inhibitory effect for OL-E in comparison with OL-L for $\alpha$-glucosidase activity ( $\mathrm{p}<0.05$, figs $3 \mathrm{C}, \mathrm{D})$.

OL-E at 50, 100 and $200 \mu \mathrm{M}$ concentrations considerably enhanced the insulin secretion to 34.09 ,
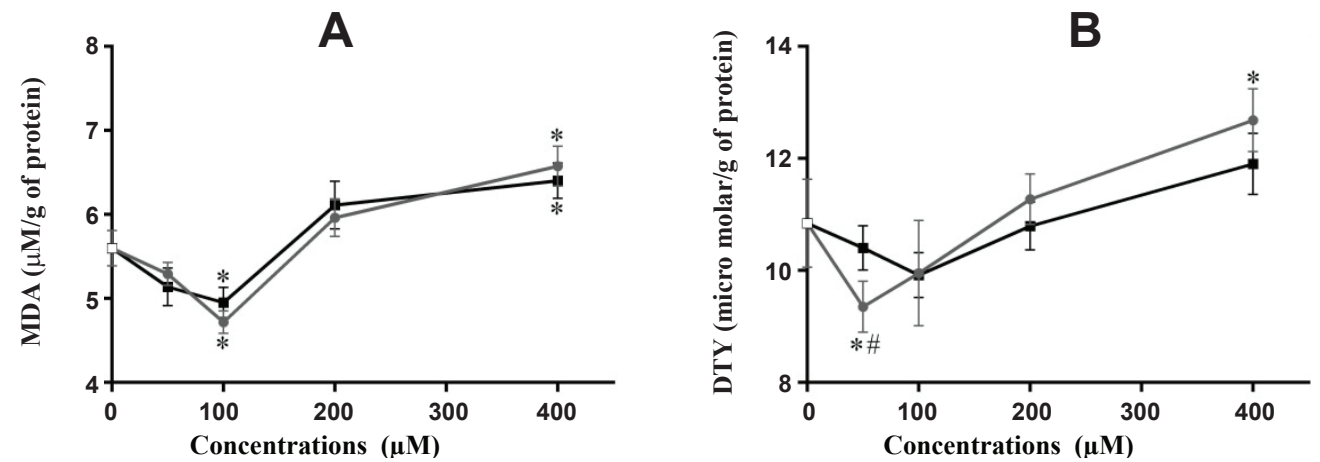

Fig. 2: Oleracein $E$ and oleracein $L$ effects on oxidative stress levels

(A and B) Malondialdehyde and dityrosine levels in $\beta$-TC-6 pancreatic cells as $\mu \mathrm{M} / \mathrm{g}$ of protein after $24 \mathrm{~h}$ treatment with different

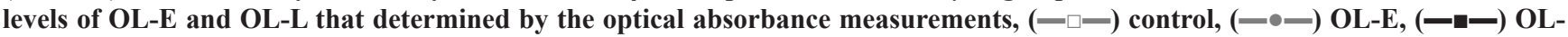
L. Biological response of each compound evaluated independently in cell lysate samples. All data are presented as mean \pm SD; $\mathbf{n}=3$. *Significant difference at $\mathbf{p}<\mathbf{0 . 0 5}$ in comparison to control according to one-way ANOVA, followed by Tukey's post hoc test. "Significant difference of OL-E compared to OL-L at the same concentration
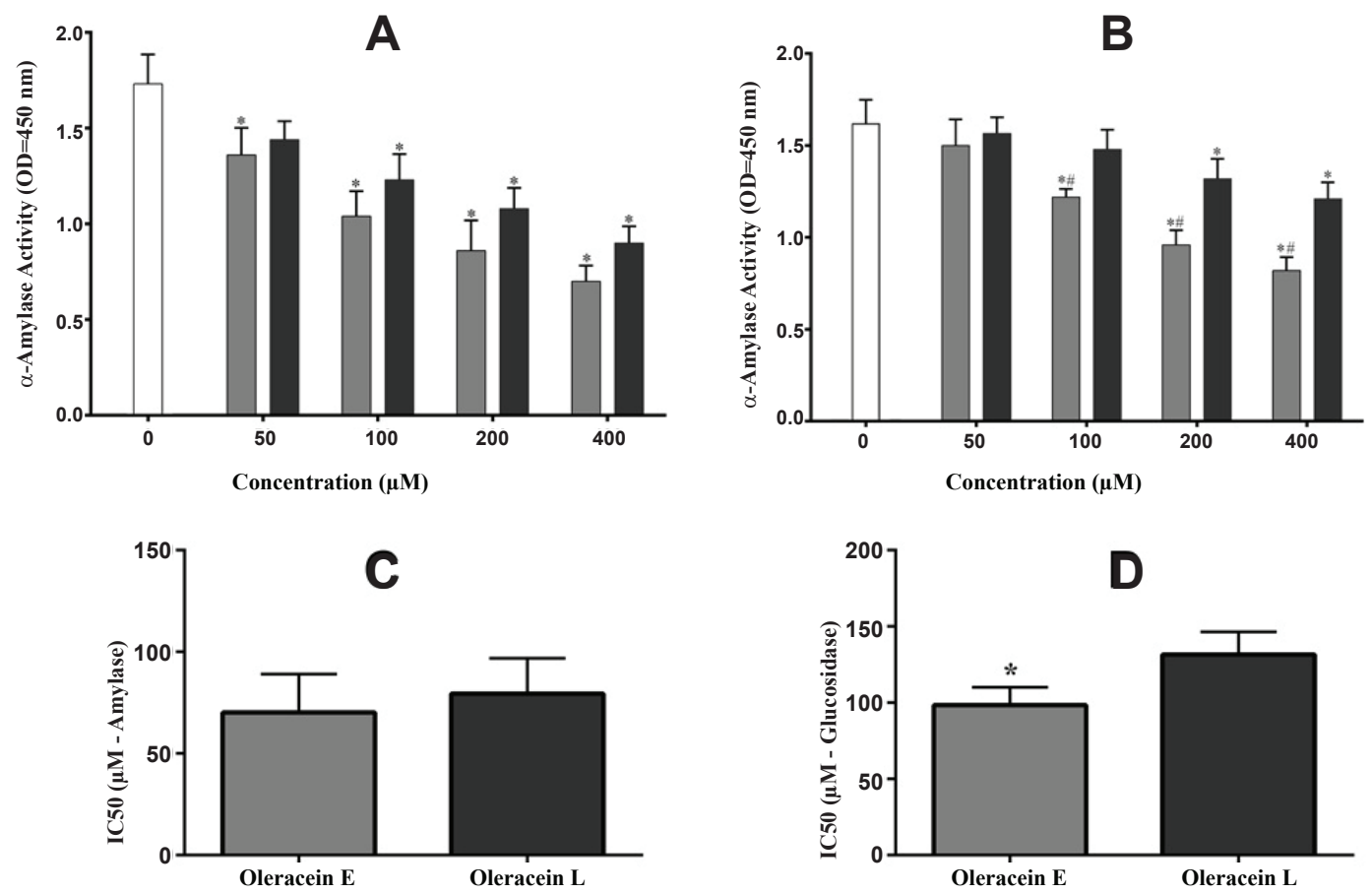

Fig. 3: Oleracein $E$ and oleracein $L$ effects on $\alpha$-amylase and $\alpha$-glucosidase inhibitory activities

(A and B) $\alpha$-Amylase and $\alpha$-glucosidase activities of $\beta$-TC-6 pancreatic cells after $24 \mathrm{~h}$ treatment with different concentrations of OL-E and OL-L that evaluated by the optical absorbance measurements, ( $\square$ ) control, ( $\square)$ OL-E, ( $\square$ ) OL-L. Biological response of each compound assessed separately in samples. All data are presented as mean \pm SD; $n=3$. *Significant difference at $p<0.05$ in comparison to control according to one-way ANOVA, followed by Tukey's post hoc test. "Significant difference of OL-E compared to OL-L at the same concentration. (C and D) IC50 values of studied derivatives for $\alpha$-amylase and $\alpha$-glucosidase activities in pancreatic cells. All data are shown as mean \pm SD. *Significant difference at $\mathbf{p}<0.05$ in comparison to OL-L group 
47.36 and $16.93 \%$, respectively, compared to the control. In addition, 50, 100 and $200 \mu \mathrm{M}$ concentrations of OL-L remarkably increased the insulin secretion to $16.70,32.26$ and $11.44 \%$, respectively, relative to the control (fig. 4A).

OL-L at 100, 20 and $400 \mu \mathrm{M}$ concentrations remarkably increased glucose uptake to $17.4,27.1$ and $39.8 \%$, respectively, compared to the control. In addition, 100, 200 and $400 \mu \mathrm{M}$ concentrations of OL-E considerably enhanced increased the glucose uptake to $31.5,59.7$
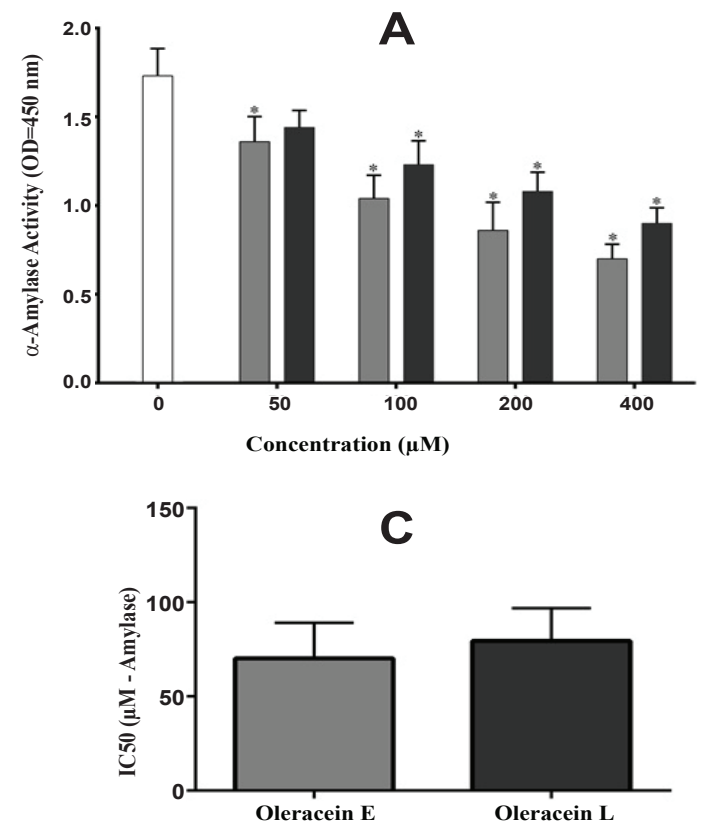

and $73.5 \%$, respectively, compared to the control (fig. 4B).

The effects of two studied tetrahydroisoquinoline on the viability of $\beta$-TC- 6 pancreatic cells with MTT assay are presented in fig. 5. Any significant cellular toxicity was observed in the low to moderate dose of studied compounds. At concentrations higher than $100 \mu \mathrm{M}$, both OL-L and OL-E could decrease cell survival $(\mathrm{p}<0.05)$ and there was no difference between them in this respect.
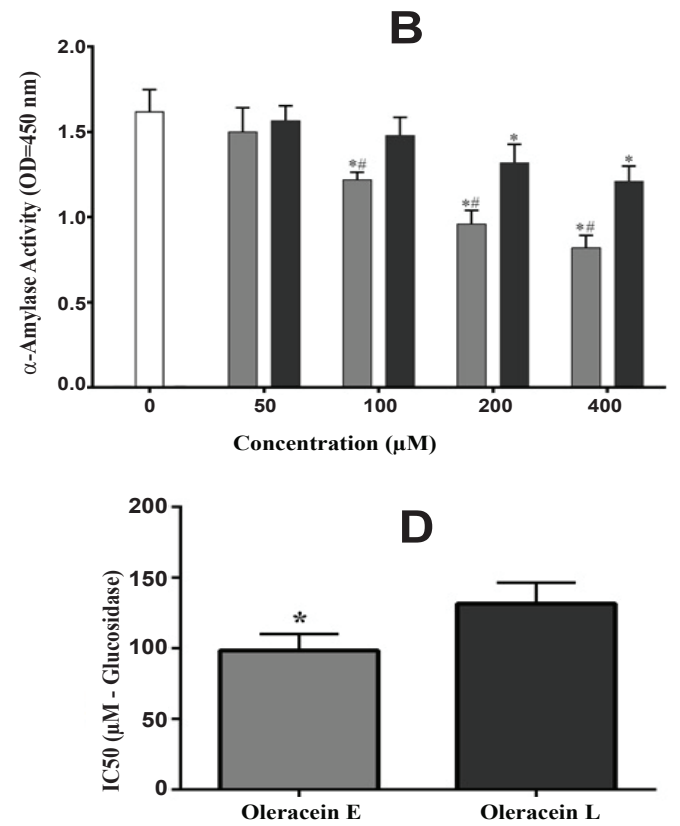

Fig. 4: Oleracein $E$ and oleracein $L$ effects on insulin secretion and glucose uptake levels

(A and B) Insulin secretion and glucose uptake levels in $\beta$-TC-6 pancreatic cells as $\mathrm{mg} / \mathrm{g}$ protein and nmol/g protein respectively after $24 \mathrm{~h}$ treatment with different levels of OL-E and OL-L that determined by serologic assay kit and measurements of fluorescence intensity excitation/emission respectively, $(\square)$ control, ( $\square)$ OL-E, ( $\square)$ OL-L. Data of each compound evaluated independently in cell lysate samples and presented as mean $\pm \mathrm{SD} ; \mathbf{n}=\mathbf{3}$. *Significant difference at $\mathbf{p}<\mathbf{0 . 0 5}$ in comparison to control according to one-way ANOVA, followed by Tukey's post hoc test. "Significant difference of OL-E compared to OL-L at the same concentration
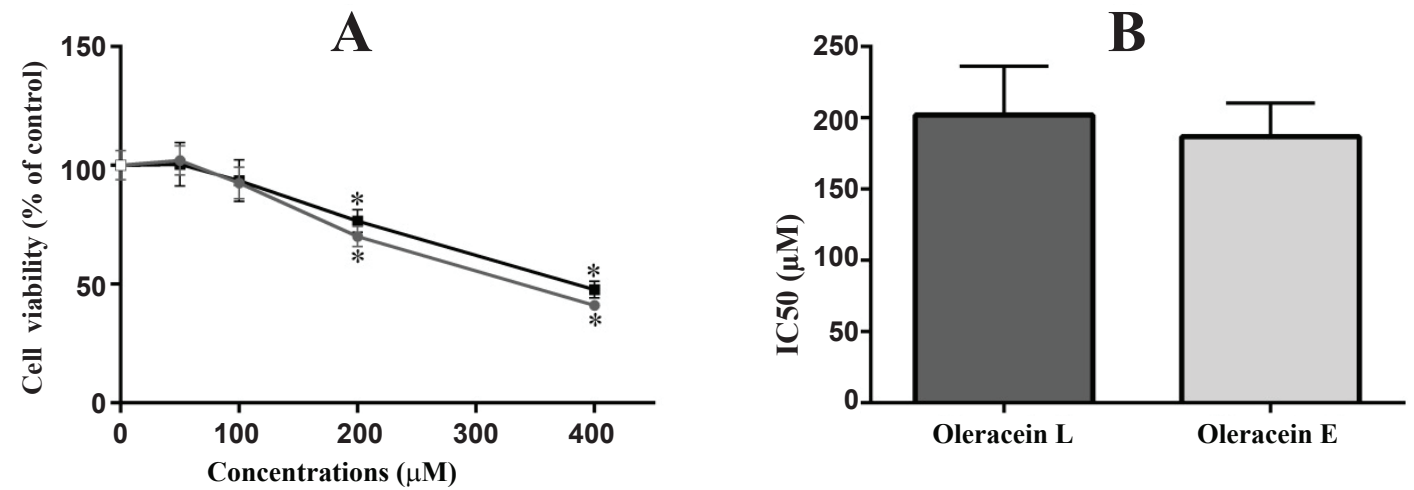

Fig. 5: Cell viability and IC50 values of investigated derivatives for cell viability in $\beta$-TC-6 pancreatic cells

(A) Cell viability of $\beta$-TC-6 pancreatic cells as the percent of control after $24 \mathrm{~h}$ treatment with different concentrations of Oleracein $\mathrm{E}$ (OL-E) and oleracein L (OL-L) that determined by the MTT assay. Biological response of each compound determined independently in cell lysate samples, $(-\square-)$ control, $(-\bullet-)$ OL-E, $(-\square-)$ OL-L. All data are described as mean survival relative to the untreated control \pm SD; $\mathbf{n}=3$. *Significant difference at $\mathbf{p}<\mathbf{0 . 0 5}$ in comparison to control according to one-way ANOVA, followed by Tukey's post hoc test. (B) IC50 values of investigated derivatives for cell viability in $\beta-T C-6$ pancreatic cells. All data are shown as mean \pm SD. There was no statistically significant difference between OL-E and OL-L 
Portulaca oleracea was known as an effective and safe complementary therapy for DM without any hypoglycemic, hypolipidemic and insulin resistance side effects $^{[20]}$. The suppression of hyperglycemia, diabetic vascular inflammation, and prevention of the diabetic endothelial dysfunction have been demonstrated with aqueous extract of purslane ${ }^{[35]}$.

Phenolic alkaloids, including OL-E and OL-L as a remarkable class of antioxidants in purslane ${ }^{[36]}$. In the current study, the effects of $0,50,100,200$ and $400 \mu \mathrm{M}$ concentrations of OL-E and OL-L on the activities of antioxidant enzymes, oxidative damage biomarkers and antidiabetic index levels on $\beta$-TC-6 pancreatic cell line were studied.

Persistent oxidative stress is related to DNA damage and disrupting of pancreatic islet $\beta$ cell mass, glucose toxicity, and it has been considered as central mediators of insulin resistance ${ }^{[37-39]}$. Data obtained in the present investigation confirmed that both OL-E and OL-L up to $100 \mu \mathrm{M}$ concentrations almost equally increased SOD, catalase and GPx activity in a dose-dependent fashion and on the contrary, MDA and DTY were reduced. But the concentrations above $100 \mu \mathrm{M}$, did not have such an outcome.

Several reports suggested that oxidative stress is noticeably reduced by phenolic alkaloids ${ }^{[16]}$. A study on superoxide anion scavenging activities in oleracea showed that the extract of this plant possessed superoxide scavenging activities ${ }^{[40]}$. In line with this study, several investigations were performed to study the effect of purslane on different organs. The administration of this plant inhibited oxidative stress response through the MDA reduction in liver and kidney ${ }^{[41,42]}$. Furthermore, Portulaca oleracea prevented hyperglycemia by reducing the oxidative stress and inflammation in streptozotocin-induced diabetic rats ${ }^{[43]}$.

Some experimental results showed that full-grown plants of $P$. olerecea had higher antioxidant activities compared with the plants at the immature levels. In other words, the antioxidant activities of mature Portulaca olerecea improved over different growth stages $^{[44]}$.

Phytochemicals with the ability to delay or prevent glucose absorption can be considered as a potential candidate for the management of $\mathrm{DM}^{[45]}$. $\alpha$-Amylase is involved in the cleavage of long-chain carbohydrates and $\alpha$-glucosidase breaks down starch and disaccharides to glucose $\mathrm{e}^{[46]}$. They help in intestinal glucose absorption and inhibition of them can significantly decrease the postprandial blood glucose after a mixed carbohydrate $\operatorname{diet}^{[46,47]}$.

In the current study, it was observed that carbohydrate digestive enzyme inhibited with both OL-E and OL-L in a dose-dependent manner although, OL-E was a stronger inhibitor of $\alpha$-glucosidase. The investigation of the inhibitory activity on $\alpha$-glucosidase was carried out by studying the stem and leaves of five ancient herbs. The plants studied showed various antioxidant and $\alpha$-glucosidase inhibitor activities. Lee et al. demonstrated that Neptunia oleracea may be recommended as a natural antioxidant and antidiabetic compound used to treat $\mathrm{DM}^{[48]}$. Also, $\alpha$-glucosidase and $\alpha$-amylase enzyme inhibitory effects of Andrographis paniculata extract have been studied by Subramanian and co-workers ${ }^{[46]}$.

Present data revealed that moderate concentrations $(100 \mu \mathrm{M})$ of OL-E and OL-L had a positive effect on insulin secretion. Also, high concentrations of studied compounds (200 $\mu \mathrm{M}$ and higher) increased glucose uptake with $\beta$-TC-6 pancreatic cells. Purslane has been reported to decrease the blood sugar and cause insulin secretion by restoring the impaired pancreatic cells in diabetic rats ${ }^{[49,50]}$. The hypoglycemic effects of Portulaca oleracea $L$ make it useful for the treatment of diseases such as $\mathrm{DM}^{[49,50]}$. Essential alkaloids derived from purslane can directly correlate the antioxidant activity of the enzymes and antidiabetic indicators given the relationship between antioxidant activity and antidiabetic indication. This plant could be suggested for future studies as a decent supply of nutrition, which can protect the body, due to its high alkaloid content.

Finally, it was demonstrated that the low dose of oleracein derivatives (in the range of $100 \mu \mathrm{M}$ ) does not have any considerable cytotoxicity. Unlike the tumor cells, some other studies have even shown the cytoprotective properties of OL-E on dopaminergic neurons and adipose cells ${ }^{[51,52,22]}$.

The results of the present study showed that moderate concentration of both OL-E and OL-L tested as phenolic alkaloids in $\beta$-TC- 6 pancreatic cell line reveal potential antioxidant and $\alpha$-amylase and $\alpha$-glucosidase inhibitory properties. Oleracein derivatives were different in their bioactivities and the study exhibited that OL-E could be greater contributors than OL-L to the $\alpha$-glucosidase inhibition activities. The results proposed that oleracein compounds are the considerable contributor capabilities to the antioxidant, 
$\alpha$-glucosidase inhibitory, stimulating effect on insulin secretion and improving glucose uptake of Portulaca oleracea. Consequently, OL-E and OL-L could be recommended as a potential natural antioxidant and antidiabetic compounds in order to protect pancreas against ROS and the prevention or the treatment of DM and its complications. Further studies are necessary to complete and confirm our experimental results. Nonetheless, the use of this plant as an alternative remedy for diabetes requires more extensive studies or the optimum extraction and isolation of the other bioactive isoquinoline derivatives and its safety and efficacy evaluation on human subjects.

\section{Conflicts of interest:}

The authors declare no conflicts of interest.

\section{REFERENCES}

1. Blair M. Diabetes Mellitus Review. Urol Nurs 2016;36(1):2736.

2. Chawla A, Chawla R, Jaggi S. Microvascular and macrovascular complications in diabetes mellitus: distinct or continuum? Indian J Endocrinol Metab 2016;20(4):546-51.

3. Fu Z, R Gilbert E, Liu D. Regulation of insulin synthesis and secretion and pancreatic Beta-cell dysfunction in diabetes. Curr Diabetes Rev 2013;9(1):25-53.

4. Rains JL, Jain SK. Oxidative stress, insulin signaling, and diabetes. Free Radic Biol Med 2011;50(5):567-75.

5. Niedernhofer LJ, Daniels JS, Rouzer CA, Greene RE, Marnett LJ. Malondialdehyde, a product of lipid peroxidation, is mutagenic in human cells. J Biol Chem 2003;278(33):3142633.

6. Siddhuraju P, Becker K. Antioxidant properties of various solvent extracts of total phenolic constituents from three different agroclimatic origins of drumstick tree (Moringa oleifera Lam.) leaves. J Agric Food Chem 2003;51(8):214455.

7. Halliwell B. Lipid peroxidation, antioxidants and cardiovascular disease: how should we move forward? Cardiovasc Res 2000;47(3):410-8.

8. DiMarco T, Giulivi C. Current analytical methods for the detection of dityrosine, a biomarker of oxidative stress, in biological samples. Mass Spectrom Rev 2007;26(1):108-20.

9. Teng H, Chen L. $\alpha$-Glucosidase and $\alpha$-amylase inhibitors from seed oil: A review of liposoluble substance to treat diabetes. Crit Rev Food Sci Nutr 2017;57(16):3438-48.

10. Tundis R, Loizzo MR, Menichini F. Natural products as $\alpha$-amylase and $\alpha$-glucosidase inhibitors and their hypoglycaemic potential in the treatment of diabetes: an update. Mini Rev Med Chem 2010;10(4):315-31.

11. Kooti W, Farokhipour M, Asadzadeh Z, Ashtary-Larky D, Asadi-Samani M. The role of medicinal plants in the treatment of diabetes: a systematic review. Electron Physician 2016;8(1):1832-42.

12. Karimi G, Khoei A, Omidi A, Kalantari M, Babaei J, Taghiabadi E, et al. Protective effect of aqueous and ethanolic extracts of Portulaca oleracea against cisplatin induced nephrotoxicity. Iran J Basic Med Sci 2010;13(2):31-5.

13. Xiang L, Xing D, Wang W, Wang R, Ding Y, Du L. Alkaloids from Portulaca oleracea L. Phytochemistry 2005;66(21):2595-601.

14. Chen T, Wang J, Li Y, Shen J, Zhao T, Zhang H. Sulfated modification and cytotoxicity of Portulaca oleracea L. polysaccharides. Glycoconj J 2010;27(6):635-42.

15. Dong CX, Hayashi K, Lee JB, Hayashi T. Characterization of structures and antiviral effects of polysaccharides from Portulaca oleracea L. Chem Pharm Bull 2010;58(4):507-10.

16. Tiong SH, Looi CY, Hazni H, Arya A, Paydar M, Wong WF, et al. Antidiabetic and antioxidant properties of alkaloids from Catharanthus roseus (L.) G. Don. Molecules 2013;18(8):977084.

17. Sharma B, Salunke R, Balomajumder C, Daniel S, Roy P. Anti-diabetic potential of alkaloid rich fraction from Capparis decidua on diabetic mice. J Ethnopharmacol 2010;127(2): 457-62.

18. Liu L, Howe P, Zhou YF, Xu ZQ, Hocart C, Zhang R. Fatty acids and beta-carotene in australian purslane (Portulaca oleracea) varieties. J Chromatogr A 2000;893(1):207-13.

19. Zidan Y, Bouderbala S, Djellouli F, Lacaille-Dubois MA, Bouchenak M. Portulaca oleracea reduces triglyceridemia, cholesterolemia, and improves lecithin: cholesterol acyltransferase activity in rats fed enriched-cholesterol diet. Phytomedicine 2014;21(12):1504-8.

20. El-Sayed MI. Effects of Portulaca oleracea L. seeds in treatment of type-2 diabetes mellitus patients as adjunctive and alternative therapy. J Ethnopharmacol 2011;137(1):643-51.

21. Pakdel R, Niazmand S, Mouhebati M, Vahedi MM, Aghaee A, Hadjzadeh MA. A comparison between the effects of Portulaca oleracea seeds extract and valsartan on echocardiographic and hemodynamic parameters in rats with levothyroxine-induced thyrotoxicosis. Avicenna J Phytomed 2018;8(3):276-85.

22. Sun H, He X, Liu C, Li L, Zhou R, Jin T, et al. Effect of Oleracein E, a Neuroprotective Tetrahydroisoquinoline, on Rotenone-Induced Parkinson's Disease Cell and Animal Models. ACS Chem Neurosci 2016;8(1):155-64.

23. Jiao ZZ, Yue S, Sun HX, Jin TY, Wang HN, Zhu RX, et al. Indoline amide glucosides from Portulaca oleracea: isolation, structure, and DPPH radical scavenging activity. J Nat Prod 2015;78(11):2588-97.

24. Poitout V, Stout LE, Armstrong MB, Walseth TF, Sorenson RL, Robertson RP. Morphological and functional characterization of beta TC-6 cells--an insulin-secreting cell line derived from transgenic mice. Diabetes 1995;44(3):306-13.

25. Kono Y. Generation of superoxide radical during autoxidation of hydroxylamine and an assay for superoxide dismutase. Arch Biochem Biophys 1978;186(1):189-95.

26. Aebi H. Catalase in vitro. Methods Enzymol 1984;105:121-6.

27. Flohé L, Günzler WA. Assays of glutathione peroxidase. Methods Enzymol 1984;105:114-21.

28. Wills ED. Mechanisms of lipid peroxide formation in animal tissues. Biochem J 1966;99(3):667.

29. Amadò R, Aeschbach R, Neukom H. Dityrosine: in vitro production and characterization. Methods Enzymol 1984;107:377-88.

30. Apostolidis E, Kwon YI, Shetty K. Inhibitory potential of herb, fruit, and fungal-enriched cheese against key enzymes linked to type 2 diabetes and hypertension. Innov Food Sci Emerg Technol 2007;8(1):46-54.

31. Shinde J, Taldone T, Barletta M, Kunaparaju N, Hu B, Kumar 
$\mathrm{S}$, et al. $\alpha$-Glucosidase inhibitory activity of Syzygium cumini (Linn.) Skeels seed kernel in vitro and in Goto-Kakizaki (GK) rats. Carbohydr Res 2008;343(7):1278-81.

32. Loaiza A, Porras OH, Barros LF. Glutamate triggers rapid glucose transport stimulation in astrocytes as evidenced by real-time confocal microscopy. J Neurosci 2003;23(19):733742.

33. DeFronzo RA, Tobin JD, Andres R. Glucose clamp technique: a method for quantifying insulin secretion and resistance. Am J Physiol 1979;237(3):E214-23.

34. Young FM, Phungtamdet W, Sanderson BJ. Modification of MTT assay conditions to examine the cytotoxic effects of amitraz on the human lymphoblastoid cell line, WIL2NS. Toxicol In Vitro 2005;19(8):1051-9.

35. Lee AS, Lee YJ, Lee SM, Yoon JJ, Kim JS, Kang DG, et al. Portulaca oleracea ameliorates diabetic vascular inflammation and endothelial dysfunction in $\mathrm{db} / \mathrm{db}$ mice. Evid Based Complement Alternat Med 2012;2012:741824.

36. Yang Z, Liu C, Xiang L, Zheng Y. Phenolic alkaloids as a new class of antioxidants in Portulaca oleracea. Phytother Res 2009;23(7):1032-5.

37. Robertson RP. Chronic oxidative stress as a cenetral mechanism for glucose toxicity in pancreatic islet beta cells in diabetes. J Biol Chem 2004;279(41):42351-4.

38. Sakuraba H, Mizukami H, Yagihashi N, Wada R, Hanyu $\mathrm{C}$, Yagihashi S. Reduced beta-cell mass and expression of oxidative stress-related DNA damage in the islet of Japanese Type II diabetic patients. Diabetologia 2002;45(1):85-96.

39. Evans JL, Goldfine ID, Maddux BA, Grodsky GM. Are oxidative stress-activated signaling pathways mediators of insulin resistance and beta-cell dysfunction? Diabetes 2003;52(1):1-8.

40. Siriamornpun S, Suttajit M. Microchemical components and antioxidant activity of different morphological parts of Thai wild purslane (Portulaca oleracea). Weed Sci 2010;58(3):182-8.

41. Yang X, Yan Y, Li J, Tang Z, Sun J, Zhang H, et al. Protective effects of ethanol extract from Portulaca oleracea L on dextran sulphate sodium-induced mice ulcerative colitis involving anti-inflammatory and antioxidant. Am J Transl Res 2016;8(5):2138-48.

42. Guo G, Yue L, Fan S, Jing S, Yan LJ. Antioxidant and
Antiproliferative Activities of Purslane Seed Oil. J Hypertens 2016;5(2):218.

43. Samarghandian S, Borji A, Farkhondeh T. Attenuation of Oxidative Stress and Inflammation by Portulaca oleracea in Streptozotocin-Induced Diabetic Rats. J Evid Based Complementary Altern Med 2017;22(4):562-6.

44. Uddin MK, Juraimi AS, Ali ME, Ismail MR. Evaluation of antioxidant properties and mineral composition of purslane (Portulaca oleracea L.) at different growth stages. Int J Mol Sci 2012;13(8):10257-67.

45. Andrade-Cetto A, Becerra-Jiménez J, Cárdenas-Vázquez R. Alfa-glucosidase-inhibiting activity of some Mexican plants used in the treatment of type 2 diabetes. J Ethnopharmacol 2008;116(1):27-32.

46. Subramanian $\mathrm{R}$, Asmawi MZ, Sadikun A. In vitro alphaglucosidase and alpha-amylase enzyme inhibitory effects of Andrographis paniculata extract and andrographolide. Acta Biochim Pol 2008;55(2):391-8.

47. Kumar S, Narwal S, Kumar V, Prakash O. $\alpha$-glucosidase inhibitors from plants: A natural approach to treat diabetes. Pharmacogn Rev 2011;5(9):19-29.

48. Lee SY, Mediani A, Nur Ashikin AH, Azliana AB, Abas F. Antioxidant and $\alpha$-glucosidase inhibitory activities of the leaf and stem of selected traditional medicinal plants. Int Food Res J 2014;21(1):165-72.

49. Gong F, Li F, Zhang L, Li J, Zhang Z, Wang G. Hypoglycemic effects of crude polysaccharide from purslane. Int J Mol Sci 2009;10(3):880-8.

50. Ramadan BK, Schaalan MF, Tolba AM. Hypoglycemic and pancreatic protective effects of Portulaca oleracea extract in alloxan induced diabetic rats. BMC Complement Altern Med 2017;17(1):37.

51. Guo ZQ, Guo Q, Zhu ZX, Zhang SY, Li C, Chai XY, et al. Chemical constituents from a Tibetan medicine Meconopsis horridula. Zhongguo Zhong Yao Za Zhi 2014;39(7):1152-56.

52. Xiao FY, Lu FE, Xu LJ. Effect of different parts of Portulace oleracea on the levels of TNF-alpha and IL-6 in the supernatant of cultured adipose cell. Zhongguo Zhong Yao Za Zhi 2005;30(22):1763-66. 